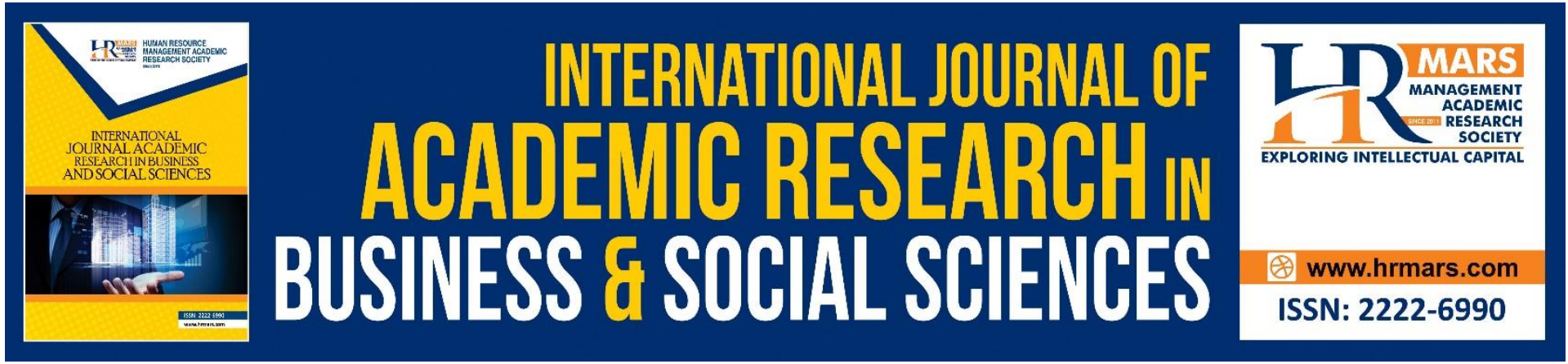

\title{
The Sustainability of Malaysia Purple Sweet Potato and Its Nutritional Value: Product Development Perspective
}

Rosmaliza Muhammad, Norazmir Md Nor, Emmy Hainida Khairul Ikram, Mohd Shazali Md Sharif

To Link this Article: http://dx.doi.org/10.6007/IJARBSS/v11-i8/10732 DOI:10.6007/IJARBSS/v11-i8/10732

Received: 02 June 2021, Revised: 24 June 2021, Accepted: 23 July 2021

Published Online: 13 August 2021

In-Text Citation: (Muhammad et al., 2021)

To Cite this Article: Muhammad, R., Nor, N. M., Ikram, E. H. K., \& Sharif, M. S. M. (2021). The Sustainability of Malaysia Purple Sweet Potato and Its Nutritional Value: Product Development Perspective. International Journal of Academic Research in Business and Social Sciences, 11(8), 302-310.

Copyright: @ 2021 The Author(s)

Published by Human Resource Management Academic Research Society (www.hrmars.com)

This article is published under the Creative Commons Attribution (CC BY 4.0) license. Anyone may reproduce, distribute, translate and create derivative works of this article (for both commercial and non-commercial purposes), subject to full attribution to the original publication and authors. The full terms of this license may be seen at: http://creativecommons.org/licences/by/4.0/legalcode

Vol. 11, No. 8, 2021, Pg. 302 - 310

Full Terms \& Conditions of access and use can be found at http://hrmars.com/index.php/pages/detail/publication-ethics 


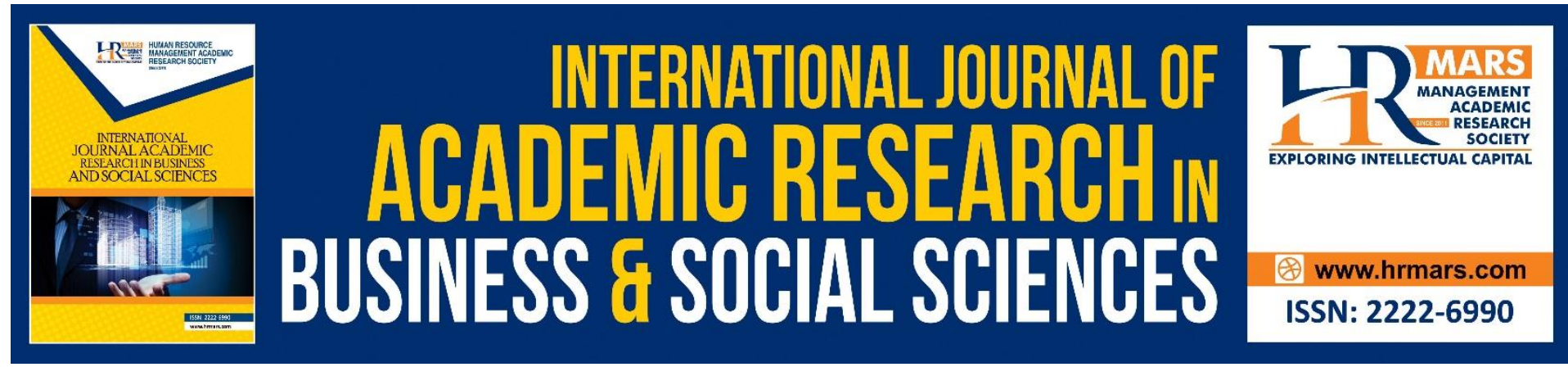

\title{
The Sustainability of Malaysia Purple Sweet Potato and Its Nutritional Value: Product Development Perspective
}

\author{
Rosmaliza Muhammad, Norazmir Md Nor, Emmy Hainida \\ Khairul Ikram, Mohd Shazali Md Sharif \\ Universiti Teknologi MARA, Malaysia
}

\begin{abstract}
Purple sweet potato is a unique crop. With various health benefits and nutritional values, there are still a lacks consumption of this crop among consumers, especially Malaysians. Besides high in dietary fiber, it also has a low glycemic index, contain proteins, minerals, polyphenols, and anthocyanin. Therefore, it could become an alternative crop for people who have less fiber intake in dietary pattern. The crop also found as anti-oxidative, hepatoprotective, anti-inflammatory, anti-tumor, anti-diabetic, anti-microbial, anti-obesity, and anti-ageing effects. Purple sweet potato is an unpopular crop for Malaysians due to a lack of commercial food products based on this crop. Normally, only a few types of Malaysian desserts and traditional snacks are produced from purple sweet potato. Nevertheless, it is still neglected by Malaysian consumers. Without a doubt, purple sweet potato can be commercialized globally due to its various health benefits and nutritional values. To ensure the sustainability of Malaysia purple sweet potato, this local crop needs to be developed and produced in various types of food products such as cracker, bread, cakes and cookies to prolong its shelf life. Hence, it has good potential commercialization purposes through the product development process on a big scale.
\end{abstract}

Keywords: Purple Sweet Potato, Sustainability, Nutritional Value, Product Development, Malaysia

\section{Introduction}

Sweet potato or Ipomoea batatas is a crop that cultivated extensively for its nutritious and health-promoting values (FAO, 2012; Lee et al., 2012). It also plays an important role in food security. Moreover, sweet potato is a healthy food recommended by the FAO of the United Nations (Jang et al., 2019) because of the presence of beneficial nutrients such as $\beta$ carotene, anthocyanins, vitamin B1, B2, C and E as well as minerals such as $\mathrm{Ca}, \mathrm{Mg}, \mathrm{K}$, and $\mathrm{Zn}$ (Liu et al., 2017; Kim et al., 2012). It is interesting to note that sweet potato is becoming a research focus in recent years due to its unique nutritional and functional properties. Besides that, carbohydrates, proteins, lipids, carotenoids, anthocyanins, conjugated phenolic acids and minerals in different parts (tubers, leaves, stems and stalks) of sweet potato (Wang et al., 2016). 
The unique composition of sweet potato contributes to its various health benefits such as anti-oxidative, hepatoprotective, anti-inflammatory, anti-tumor, anti-diabetic, antimicrobial, anti-obesity, anti-ageing effects (Wang et al., 2016). Therefore, there has been increasing interest in using sweet potato for food formulation and human consumption due to their attractive nutritional profile. In addition, Zhu and Sun (2019) discovered that the health benefits of sweet potato are related to the attributes of various bioactive components such as dietary fibre, polyphenols, proteins, and minerals present in sweet potatoes.

Therefore, there is the possibility to use sweet potatoes in food formulation and production to enhance the nutritional values. According to Cui and Zhu (2019) and Zhu and Wang (2014), sweet potato root or tuber is rich in starch and has similar processing properties as cereals. Processing fresh sweet potato root can also extend its applications and shelf life, especially to the obese population, since scholars have proven it as an anti-obesity food (Wang et al., 2016). Not only that, but its root also tends to contain a high level of $\alpha$-amylase (Cui \& Zhu, 2019; Collado \& Corke, 1999).

There are different types of sweet potato roots with different colours. For instance, orange-fleshed sweet potato, yellow-fleshed sweet potato, and purple-fleshed sweet potato are the major types. Among all, purple-fleshed sweet potato roots are of special interest due to anthocyanins and other polyphenols (Zhu, Cai, Yang, Ke, \& Corke, 2010). Polyphenols contribute to the good antioxidant and other biological activities of the root. Whole sweet potato root is also rich in soluble and insoluble dietary fibres (Wang et al., 2016). High contents of dietary fibre and polyphenols may reduce starch digestibility (Singh, Dartois \& Kaur, 2010; Zhu, 2015). Hence, sustaining sweet potato through food development will increase its value-added and commercialization level.

\section{Literature Review}

Sweet potato is the sixth important food crop and main carbohydrate source in the world. It is also known as a staple food source for many populations, especially in Africa, Indonesia, Central and South America, Japan, the Caribbean, Polynesia, Hawaii and Papua New Guinea (Giri, Ambedkar \& Sakhale, 2019). According to Food and Agriculture Organization (FAO) (2016), sweet potato has become an important crop for developing countries but less important in some other countries. For instance, China is the major producer of sweet potato, contributing 80 to $85 \%$ of total production globally.

Nevertheless, Giri, Ambedkar and Sakhale (2019) reported that sweet potato is one of the most under-exploited food crops although it has various nutritional benefits. It can be seen as Grant (2003) revealed that in the past few years, sweet potato is also known for the "food security" or "famine relief" crop, particularly in developing countries. It is a low input crop and is used as a vegetable, a desert, a source of starch and animal feed (Bibiana, Grace \& Juliu, 2014). They further stated that sweet potato in Nigeria is mostly consumed as a snack called asondo, roasted, boiled, used with fresh yams and sweetener in beverage production. Furthermore, this tuber crop and other tropical crops play a vital role in food security and nutrition and climate change adaptation (Giri, Ambedkar \& Sakhale, 2019). The root and tuber crops are essential components of diet in many countries (Odebode, 2004).

In Malaysia, the Department of Agriculture Peninsular Malaysia reported in Vegetables and Cash Crops Statistics Malaysia (2018) that sweet potato production in Malaysia was only 4,634.79 metric tons, which is sixth compared to other crops like maize, tapioca, yam, sugar cane and yam bean. The planted area of sweet potato was 811.10 hectarage $(\mathrm{Ha})$, but the harvested area was only $601.17 \mathrm{Ha}$. The highest sweet potato 
production in Malaysia was from Peninsular Malaysia compared to Sabah, Sarawak, and Wilayah Persekutuan Labuan. Their overall production was 41,245.0 Mt with $39266.60 \mathrm{Mt}$ from Peninsular Malaysia compared to $1978.40 \mathrm{Mt}$ for 2017. It can be seen the decline production rate of sweet potato from 2013 to 2017. For instance, in 2015, there was 48,378.90 Mt production in Peninsular Malaysia and 2.228.50 Mt in Sabah, Sarawak and Wilayah Persekutuan Labuan. Nevertheless, the production figure dropped in 2017.

Based on the sweet potato price, FAMA in 2015 reported that the farm price for sweet potato was RM1390 per tons, RM2190 per tons for the wholesale price and RM3300 per tons for retail price. The price increased in 2016 whereby RM1640 per tons for farm price, followed by RM2780 per tons for the wholesale price and RM4030 per tons for retail price. Nevertheless, all the sweet potato prices per tons decreased in 2017, whereby the farm price was RM1660 per tons, RM2600 per tons for the wholesale price and RM3850 for retail price. It clearly showed that local sweet potato, especially purple sweet potato (PSP), in Malaysia has low demand and lack of consumption among Malaysian households.

From a culinary perspective, sweet potato, especially purple sweet potato, is not the major ingredients in most traditional dishes, including Malay traditional food. Not only that, but dessert is also the only meal course that consumers normally use purple sweet potato in Malay traditional food preparation. Desserts such as che mek molek (Kelantan kuih) and bubur keledek are examples of Malay traditional food that use orange sweet potato but not purple. Most Malaysians only eat boiled sweet potato root, especially the purple sweet potato. Most children, adolescents and young adults do not prefer to eat purple sweet potato. It is a common phenomenon in the supermarket whereby most of the local PSPs are unsold compared to the other local vegetables. Due to that, its retail price is unstable, which was a little bit higher in 2016 but lower in 2017. Recently, few manufacturers have produced snacks from sweet potato to add snack varieties without promoting its health benefits to the population. Nonetheless, the local PSP with high nutritional values is still abandoned.

According to the United States Department of Agriculture National Nutrient Database (2015), the nutritional value for $100 \mathrm{~g}$ of PSP contains water 77.28g; energy 86 kcalorie, carbohydrates $20.12 \mathrm{~g}$, protein $1.57 \mathrm{~g}$, total fibre, $3 \mathrm{~g}$ and total lipid $0.05 \mathrm{~g}$. For vitamins, Vitamin A is $14187 \mathrm{IU}$, thiamine $0.078 \mathrm{mg}$, riboflavin $0.061 \mathrm{mg}$, niacin $0.557 \mathrm{mg}$, vitamin B6 $0.209 \mathrm{mg}$, Folate (vitamin B9) $11 \mu \mathrm{g}$, vitamin C $2,4 \mathrm{mg}$ and vitamin $\mathrm{K} 1.811 \mu \mathrm{g}$. On minerals, potassium is the highest mineral $(337 \mathrm{mg}$ ) in PSP. In addition, it contains sodium $55 \mathrm{mg}$, phosphorus $47 \mathrm{mg}$, calcium $30 \mathrm{mg}$, magnesium $25 \mathrm{mg}$ and iron $0.61 \mathrm{mg}$. For lipids, the amount of fatty acids on total saturated is $0.018 \mathrm{~g}$, total monounsaturated is $0.001 \mathrm{~g}$, and polyunsaturated fatty acid is $0.014 \mathrm{~g}$. Due to its nutritional value, many scholars researched PSP. Some of the products focused on by the scholars are dehydrated chips, flour, composite flour, puree, flakes, glutenfree cookies, biscuits, crackers, bread, flatbread, pancake, pasta, pasta-fibre rich, pastaprotein rich, pasta-RS enriched, noodles, spaghetti-Low Gl, extrudate snack (fasting purpose), buns and chapati, cake, cookies and buns and non-alcoholic beverages (Giri, Ambedkar \& Sakhale, 2019).

Björck, Liljeberg and Ostman (2000) reported that sweet potato is a valuable medicinal plant. It is an anti-cancer, anti-diabetic, and anti-inflammatory activities. They further contended that as a carbohydrate-rich food, sweet potato is also reported to have a low glycaemic index $(<55)$, suggesting its suitability as a portion of food for diabetic people. Low glycemic food is normally used to treat type 2 diabetes mellitus and in weight management (Gelencsér, Gal, Hodsayi \& Salgo, 2008). Accordingly, sweet potato is reported to have a low 
GI, which is highly contained in the white-skinned sweet potatoes and is used as diabeticfriendly food.

Besides that, the purple-fleshed sweet potato (PSP) has the highest concentration of anthocyanins. Truong and Avula (2010) stated that their leaf is an excellent alternative to synthetic colour in food products. Besides that, it also contains phenolics with antioxidant and anti-inflammatory activities (Grace et al., 2014). The anthocyanin content in purple-fleshed sweet potato ranges from 32 to $1390 \mathrm{mg} / 100 \mathrm{~g}$ DW as measured by pH differentialspectrophotometry or HPLC (Xu et al., 2015). Furthermore, scholars reported that sweet potato has unique chemical constituents to prevent and treat various disorders. Recently, bioactivities reported in sweet potato included anti-oxidative (Ding, Ni \& Kokot, 2015; Grace et al., 2015; Motsa, Modi \& Mabhaudhi, 2015; Zhang et al., 2014; Wu et al., 2015), antidiabetic (Zhao, Yan, Lu \& Zhang, 2013) and anti-inflammatory (Wang et al., 2014).

PSP is also used in various cooking methods such as baking, boiling, dehydrating, and frying (Wang et al., 2016). It is also produced as sweet potato starch in commercial part (Zhu \& Wang, 2014) and bioproducts (El Sheikha \& Ray, 2015). Baking gives better retention of anthocyanins in PSP than steaming. This may be because acylated phenolic acids and sugars are more degraded in steam-cooked sweet potato than in baked sweet potato (Kim, Kim et al., 2015). Thus, suitable processing methods need to be used for maximum anthocyanin retention in purple sweet potato products. Anthocyanins in purple sweet potato have also been anti-obesity (Hwang, Choi \& Han, 2011; Shin et al., 2013).

Overall, Wang et al. (2016) suggested that practical applications of underutilized sweet potatoes should be diversified as it remains much underutilized on commercial levels, focusing on optimization in formulations and processing techniques to maximize the retention of bioactive. It is also used as a new ingredient for the development of gluten-free products. Several value-added food products are being developed using sweet potato with functional elements. Sweet potato tubers could be processed into different primary products such as flour, chips, puree, and secondary products like biscuits, pasta, and noodles (Giri, Ambedkar \& Sakhale, 2019). Therefore, sweet potato can be further developed as a sustainable crop for various nutritionally enhanced food products.

Many scholars are focusing on sweet potato, particularly the purple sweet potato. Mu, Sun and Ma (2019) studied purple sweet potato as snack food. They revealed that sweet potatoes had become a research focus in recent years due to their unique nutritional and functional properties. In addition, snack foods occupy an extremely important position in the food consumption market ( $\mathrm{Mu}$, Sun \& $\mathrm{Ma}, 2019$ ). The snack food meets the consumption habits and consumption fashion of modern people for their good colour, fragrance, and taste since they are convenient for eating and offer various nutrition.

In addition, they revealed that as a kind of snack food, sweet potato snack foods have huge market potential and broad development space and noted that in recent years, sweet potato processing enterprises had introduced new technology and equipment to improve the quality of their products. They suggested that new ideas in raw materials, ingredients, flavours, texture, production, and packaging are needed to enhance sweet potato consumption. Not only that, the new type of sweet potato snack foods with various shapes and tastes needs to be developed to meet the diversified demand of market consumption since sweet potato snack foods are developing toward health.

On the other hand, Sittisak, Fuengkajornfung, Sanprom and Weenuttranon (2019) focused on the quality of cracker from purple sweet potato flour substituted for wheat flour. They concentrated on the acceptance of consumer who thinks of health. Based on the three 
types of crackers produced, the most appropriate recipe was the 1st recipe: wheat flour 400 $\mathrm{g}$, sugar $14 \mathrm{~g}$, salt $3 \mathrm{~g}$, yeast $3 \mathrm{~g}$, salted butter $80 \mathrm{~g}$, shortening $80 \mathrm{~g}$, water $180 \mathrm{~g}$. The standard recipe is then brought to the substitution of purple sweet potato flour in the $25,50,75$ percent (weight of total wheat flour), respectively. They found that the substitution of purple sweet potato flour of 50 percent had a satisfaction score between minimum in terms of taste and score to median score in terms of colour. The chemical composition of purple sweet potato flour that substitutes wheat flour in cracker found that anthocyanin was equal to 1.82 $\mathrm{mg} / 100 \mathrm{~g}$. Furthermore, they suggested a study should be conducted on the shelf life of crackers made from purple sweet potato flour, which focuses on nutritional values of crackers made from purple sweet potato flour and producing purple sweet potato in other products.

Zhu and Sun (2019) researched steamed bread's physicochemical and sensory properties fortified with purple sweet potato flour. Freeze-dried PSP was incorporated into steam bread formulations of up to $50 \%$. The results showed that PSP addition of up to $50 \%$ increased the antioxidant activities of steam bread while reducing the glycemic response. The total polyphenol/anthocyanin contents of steam bread increased with the increase of PSP level, although a portion of the polyphenols was lost during production. PSP addition of up to $50 \%$ had little effect on the water activity and water content of CSB and increased the hardness while decreasing the specific volume. Steam bread with 5-10\% PSP improved the overall sensory acceptance.

PSP can be used in steam bread of up to $10 \%$ with wheat flour to enhance the functional properties of steam bread without compromising eating quality. Overall, the results showed that PSP is suitable for use as an active ingredient in baked foods and that the functionality of the products is largely associated with the level of PSP addition. Future research should be focused on further reduction in the glycemic index of steam bread with other functional ingredients. They revealed that their study might stimulate additional interest in developing healthy CSB fortified with functional ingredients to address the everrising medical conditions among Asian and Chinese populations.

In 2011, Owusu, Oduro and Ellis studied crackers' development from cassava and sweet potato flours using Moringa oleifera and Ipomea batatas leaves as a fortification. They aimed to develop crackers enriched with Moringa oleifera and Ipomoea batatas using $100 \%$ cassava and sweet potato flour for potential use by celiac. Moringa oleifera and Ipomoea batatas enriched butter and cream crackers were made from $100 \%$ cassava flour and $100 \%$ sweet potato flour using $100 \%$ wheat flour as the control. They conducted a preliminary preference test for butter crackers and cream crackers. The best cracker was chosen for further sensory evaluation by trained panelists who evaluated each product for colour, appearance, aroma, crispness, firmness, chewiness, taste, bitter after-taste, and overall acceptability. Their results focused on proximate analysis, total phenols and beta-carotene contents. The beta-carotene levels of the leaves ranged from $4.76 \mathrm{mg} / 100 \mathrm{~g}$ to $11.54 \mathrm{mg} / 100 \mathrm{~g}$ for the sweet potato leaves, with Moringa oleifera having the highest $\beta$-carotene content of $23.43 \mathrm{mg} / 100 \mathrm{~g}$. Phenolic content ranged from $3.16 \%$ to $6.92 \%$ for sweet potato leaves and $1.51 \%$ for Moringa oleifera.

In addition, they stated that sweet potato flour crackers and cassava flour crackers had 4.87 and $3.14 ; 3.31$ and $3.20 ; 1.79$ and $1.92 ; 4.23$ and 3.29; 13.29 and $10.31 ; 77.38$ and 81.28; 446.09 and 431.02 respectively for percentages of moisture, ash, fiber, protein, fat, carbohydrates and calories. They further contended that their study demonstrated the potential for industrial exploitation of cassava and sweet potato flour by processing snack 
food items such as crackers suitable for gluten intolerants. Children can also consume the crackers, teenagers, and the elderly to provide additional nutrient and good snacking habit.

Wang, Nie and Zhu (2016) contended that practical applications of underutilized parts of sweet potatoes should be diversified, focusing on optimization in formulations and processing techniques to maximize the retention of bioactive. According to them, the current knowledge of the chemical composition of sweet potatoes and their bio-functions has been studied in-vitro and in-vivo. Nevertheless, leaves, stems and stalks of sweet potato remain much underutilized on commercial levels.

\section{Conclusion}

Thus, to promote the Malaysia purple sweet potato as novelty food product for the Malaysians and enhance the consumption of low-fat and high-fiber diet, the development of healthy cracker from local PSP warrant to produce. It is worth reiterating that the Malaysian purple sweet potato is high in fiber content, anti-obesity, antioxidant, low fat and can be an alternative snack for the Malaysian population. A study into the potential use of purple sweet potato as a healthy cracker is needed since a very limited study has been conducted to prove potential product commercialization.

\section{Corresponding Author}

Norazmir Md Nor, Universiti Teknologi MARA, Malaysia, Centre for Dietetics Studies, Faculty of Health Sciences, Universiti Teknologi MARA Puncak Alam Campus, 42300 Puncak Alam, Selangor.

Email: azmir2790@uitm.edu.my

\section{References}

Bibiana, I., Grace, N., \& Julius, A. (2014). Quality Evaluation of Composite Bread Produced from Wheat, Maize and Orange Fleshed Sweet Potato Flours. American Journal of Food Science and Technology, 2(4), 109-115. https://doi.org/10.12691/ajfst-2-4-1

Department of Agriculture. (2018). Booklet Statistik Tanaman (Sub-Sektor Tanaman Makanan) 2018. In Jabatan Pertanian (pp. 1-124).

http://www.doa.gov.my/index/resources/aktiviti_sumber/sumber_awam/maklumat _pertanian/perangkaan_tanaman/booklet_statistik_tanaman_2018.pdf

Ding, X., Ni, Y., \& Kokot, S. (2015). NIR spectroscopy and chemometrics for the discriminationof pure, powdered, purple sweet potatoes and their samples adulterated with the white sweet potato flour. Chemometrics and Intelligent Laboratory Systems, 144, 17-23.

El Sheikha, A. F., \& Ray, R. C. (2015). Potential impacts of bio-processing of sweet potato: Review. Critical Reviews in Food Science and Nutrition. http://dx.doi.org/10.1080/ 10408398.2014.960909.

FAO. (2012) (Food and Agriculture Organization of the United Nations) http://www.feedipedia.org/node/745

FAOSTAT (Statistics division of Food and Agriculture Organization of the United Nations) (2016). http://faostat3.fao.org/browse/Q/*/E

Gelencsér, T., Gal, V., Hodsayi, M., Salgo, A. (2008). Evaluation of Quality and Digestibility Characteristics of Resistant Starch Enriched Pasta. Food and Bioprocess Technology: An International Journal. 1(2):171-179. doi:10.1007/s11947-007-0040-z. 
Giri, N. A., Ambedkar, B., \& Sakhale, B. K. (2019). Sweet potato (Ipomoea batatas L.): A valuable tropical tuber crop: A review. 182, The Pharma Innovation Journal, 8(6), 182-191. www.thepharmajournal.com

Grace, M. H., Truong, A. N., Truong, V. D., Raskin, I., \& Lila,M. A. (2015). Novel value-added uses for sweet potato juice and flour in polyphenol- and protein-enriched functional food ingredients. Food Science \& Nutrition, 3, 415-424.

Grace, M. H., Yousef, G. G., Gustafson, S. J., Truong, V. D., Yencho, G. C., Lila, M. A. (2014). Phytochemical changes in phenolics, anthocyanins, ascorbic acid, and carotenoids associated with sweet potato storage and impacts on bioactive properties. Food Chemistry, 145:717-724.

Grant, V. (2003). Select markets for taro, sweet potato and yam. A report for the Rural Industries Research and Development Corporation (RIRDC). Publication No 03 /052 RIRDC project No UCQ-13A. Online: http://www.rirdc.gov.au.

Hwang, Y. P., Choi, J. H., Han, E. H., Kim, H. G.,Wee, J. H., Jung, K. O., ... Jeong, H. G. (2011b). Purple sweet potato anthocyanins attenuate hepatic lipid accumulation through activating adenosine monophosphate-activated protein kinase in human HepG2 cells and obese mice. Nutrition Research, 31, 896-906.

Jang, H. H., Kim, H. W., Kim, S. Y., Kim, S. M., Kim, J. B., Lee, Y. M. (2019). In vitro and in vivo hypoglycemic effects of cyanidin 3-caffeoyl-p-hydroxy benzoyl sophoroside-5glucoside, an anthocyanin isolated from purple-fleshed sweet potato. Food Chemistry, 272, 688-693, https://doi.org/10.1016/j.foodchem.2018.08.010

Lee, W. S., Chen, I. C., Chang, C. H., \& Yang, S. S. (2012). Bioethanol production from sweet potato by co-immobilization of saccharolytic molds and Saccharomyces cerevisiae. Renewable Energy, 39, 216-222

Liu, Y., Sun, Y., Xie, A., Yu, H., Yin, Y., Li, X., \& Duan, X. (2017). Potential of Hyperspectral Imaging for Rapid Prediction of Anthocyanin Content of Purple-Fleshed Sweet Potato Slices During Drying Process. Food Analytical Methods, 10, 3836-3846.

Motsa, N. M., Modi, A. T., \& Mabhaudhi, T. (2015). Influence of agro-ecological production areas on antioxidant activity, reducing sugar content, and selected phytonutrients of orange-fleshed sweet potato cultivars. Ciência e Tecnologia de Alimentos, 35, 32-37.

Mu, T. H., Sun, H. N., \& Ma, M. M. (2019). Sweet potato snack foods. Chemistry, Processing and Nutrition. 303-324. https://doi.org/10.1016/B978-0-12-813637-9.00011-9

Oki, T., Masuda, M., Furuta, S., Nishiba, Y., Terahara, N., Suda, I. (2002). Involvement of anthocyanins and other phenolic compounds in the radical-scavenging activity of purple-fleshed sweet potato cultivars. Journal of Food Science, 67:1752-1756.

Owusu, D., \& Oduro, I. (2011). Development of crackers from cassava and sweet potato flours using Moringa oleifera and Ipomoea batatas leaves as fortificant. American Journal of Food and Nutrition, 1(3), 114-122. https://doi.org/10.5251/ajfn.2011.1.3.114.122

Shin, S. J., Bae, U. J., Ahn, M., Ka, S. O., Woo, S. J., Noh, S. O., Park, B. H. (2013). Aqueous extracts of purple sweet potato attenuate weight gain in high fat-fed mice. International Journal of Pharmacology, 9, 42-49.

Singh, J., Dartois, A., Kaur, L. (2010). Starch digestibility in food matrix: a review. Trends in Food Science \& Technology, 21(4), 168-180. https://doi.org/10.1016/j.tifs.2009.12.001

United States Department of Agriculture National. (2015). Nutrient Database (2015), U.S Department of Agriculture, Agricultural Research Service (2000). Soft Wheat Quality Laboratory, Cereal foods world. Food Science Technology. 45(7), 303-306. 
Sittisak, A., Fuengkajornfung, N., Sanprom, T., \& Weenuttranon, J. (2019). The Quality Of Cracker From Purple Sweet Potato Flour Substituted For Wheat Flour. (145-150). International Academic Multidisciplinary Research Conference In Amsterdam 2019. http://icbtsproceeding.ssru.ac.th/index.php/ICBTSAMSTERDAM/article/view/189/18 9

Truong, V. D., Avula, R. (2010). Sweet potato purees and powders for functional food ingredients. In R. C. Ray, K. I. Tomlins, eds. Sweet potato: post-harvest aspects in food, feed and industry. Nova Science Publishers Inc., New York,117-161.

Wang. (2016). Anti-ageing and Cholesterol-lowering Activities of Cranberry and Purple Sweet Potato Anthocyanins.

Wang, S., Nie, S., \& Zhu, F. (2016). Chemical constituents and health effects of sweet potato. Food Research International,89 (1), 90-

1.https://doi.org/10.1016/j.foodres.2016.08.032

Wang, S., Nie, S., \& Zhu, F. (2016). Chemical constituents and health effects of sweet potato. In Food Research International (Vol. 89, pp. 90-116). Elsevier Ltd. https://doi.org/10.1016/j.foodres.2016.08.032

Wu, Q., Qu, H., Jia, J., Kuang, C.,Wen, Y., Yan, H., \& Gui, Z. (2015). Characterization, antioxidantand anti-tumor activities of polysaccharides from purple sweet potato. Carbohydrate Polymers, 132, 31-41

Zhang, M., Mu, T. H., \& Sun, M. J. (2014). Purification and identification of antioxidant peptidesfrom sweet potato protein hydrolysates by alcalase. Journal of Functional Foods, 7, 191-200.

Zhao, J. G., Yan, Q. Q., Lu, L. Z., \& Zhang, Y. Q. (2013). In vivo antioxidant, hypoglycemic, and anti-tumor activities of anthocyanin extracts from purple sweet potato. Nutrition Research and Practice, 7, 359-365.

Zhu, F. (2015). Interactions between starch and phenolic compound. Trends in Food Science \& Technology, 43, 129-143.

Zhu, F., \& Sun, J. (2019). Physicochemical and sensory properties of steamed bread fortified with purple sweet potato flour. Food Bioscience, 30. https://doi.org/10.1016/j.fbio.2019.04.012

Zhu, F., \& Wang, S. (2014). Physicochemical properties, molecular structure, and uses of sweet potato starch. Trends in Food Science \& Technology. 36(2), 68-78. https://doi.org/10.1016/j.tifs.2014.01.008

Zhu, F., Cai, Y. Z., Yang, X., \& Ke, J., \& Corke, H. (2010). Anthocyanins, Hydroxycinnamic Acid Derivatives, and Antioxidant Activity in Roots of Different Chinese Purple-Fleshed Sweet potato Genotypes. Journal of Agricultural and Food Chemistry. 58(13), 75887596. https://doi.org/10.1021/jf101867t 